\title{
Bank and Nonbank Competition for Small Business Credit: Evidence from the 1987 and 1993 National Surveys of Small Business Finances
}

\begin{abstract}
Rebel A. Cole and John D. Wolken, of the Board's Division of Research and Statistics, and R. Louise Woodburn, of the Internal Revenue Service, prepared this article. Amy Ashton and Ronnie McWilliams provided research assistance.
\end{abstract}

Using newly available data from the Board's 1993 National Survey of Small Business Finances together with data from the 1987 survey, we analyze competition between banks and nonbanks in the U.S. market for small business credit. According to many academics and banking practitioners, the U.S. commercial banking industry has declined. ${ }^{1}$ In particular, during the late 1980s and the early 1990s, the record number of bank failures and mergers reduced the number of commercial banks in the United States. Also, there has been an apparent decline in commercial banks' share of lending. These occurrences have raised questions about the changing role of commercial banks in providing credit to key sectors, including business lending.

Several explanations have been advanced for the decline in banks' share of business lending. In particular, technological changes in communications, information storage, and other sectors of the economy — as well as globalization—have enabled an increasing number of large firms to gain direct access to money and capital markets. The same technologi-

\footnotetext{
Note. Ms. Woodburn is on detail to the Board's Division of Research and Statistics as a sampling statistician.

1. See, for example, Allen N. Berger, Anil K. Kashyap, and Joseph M. Scalise, "The Transformation of the U.S. Banking Industry: What a Long, Strange Trip It's Been," Brookings Papers on Economic Activity, 1:1995, pp. 55-218; John H. Boyd and Mark Gertler, "Are Banks Dead? Or, Are the Reports Greatly Exaggerated?" Federal Reserve Bank of Minneapolis, Quarterly Review (Summer 1994), pp. 2-23; Franklin R. Edwards and Frederic S. Mishkin, The Decline of Traditional Banking: Implications for Financial Stability and Regulatory Policy, Working Paper 4993 (National Bureau of Economic Research, January 1995); Edward C. Ettin, "The Evolution of the North American Banking System" (paper prepared for the Experts' Meeting on Structural Changes in Financial Markets: Trends and Practices, Organization for Economic Cooperation and Development, Paris, July 11-12, 1994); and Gary Gorton and Richard Rosen, "Corporate Control, Portfolio Choice, and the Decline of Banking," Journal of Finance, vol. 50 (December 1995), pp. 1377-1420.
}

cal changes have facilitated competition from nonbank sources. Nonbanks consist of thrift institutions (savings and loan associations, savings banks, and credit unions), finance companies, insurance companies, mortgage companies, leasing companies, brokerage firms, other business firms, families and individuals, and government sources of credit.

We explore nonbank competition as an explanation for the decline in banks' share of business lending by examining sources of credit used by small firms. ${ }^{2}$ Credit here is defined as loans and capital leases, excluding credit card debt and trade credit. Because small firms are unlikely to have direct access to money and capital markets, any decline in banks' share of the aggregate dollar amount of credit provided to these firms would be consistent with the view that nonbanks are eroding this share. If banks have provided a constant or increasing share of the credit used by small firms, such evidence would run counter to the view that nonbanks are eroding this share.

We analyze the bank and nonbank shares of the dollar amount of outstanding credit to small businesses, including how these shares have changed from 1987 to 1993 . We also examine the incidence of small business borrowing from banks and nonbanks, which is defined as the percentage of firms using credit of a certain type or from a particular source. The incidence data provide a more representative view of the credit services used by a "typical" small firm than do the share data because larger firms have a greater influence on market shares than on incidence. This distinction is important because the larger firms in the survey account for the majority of the dollar amount outstanding of small business credit

2. More specifically, the results presented in this paper characterize all enterprises operating under current ownership during 1992 and with fewer than 500 full-time-equivalent employees, excluding real estate operators and lessors, real estate subdividers and developers, real estate investment trusts, agricultural enterprises, financial institutions, not-for-profit institutions, government entities, and subsidiaries controlled by other corporations. Full-time-equivalent employment is calculated as the number of full-time employees plus one-half the number of part-time employees. 
but for only a small proportion of the number of firms. For example, among small businesses, firms with more than $\$ 1$ million in sales account for more than two-thirds of credit but less than one-fifth of the number of firms.

The sources for these data-the 1987 and 1993 National Surveys of Small Business Finances (NSSBF) - are unique. ${ }^{3}$ The NSSBF is a nationally representative survey of small businesses sponsored by the Federal Reserve Board and the U.S. Small Business Administration to collect information about the sources and types of financial services obtained by small businesses. The surveys are designed to be representative of small businesses generally and provide data on bank and nonbank shares of the small business credit market. ${ }^{4}$ The NSSBF was conducted first in 1987 and again in 1993, making it possible to examine changes in market share over that period. Although the two surveys had somewhat different focuses, the data collected are sufficiently similar to allow comparisons of bank and nonbank market shares across time. ${ }^{5}$ However, differences in the cov-

3. At the time this article was written, the 1993 NSSBF data were still in the editing stage and hence subject to revision. After data edits and other processing steps are completed, an announcement about the availability of the 1993 survey data and a user's manual will appear in the Federal Reserve Bulletin.

4. For information about alternative sources of data on small businesses, see U.S. Small Business Administration, Handbook of Small Business Data, 2d ed. (Government Printing Office, 1994), and The State of Small Business: A Report of the President, 1995 (Government Printing Office, 1996).

Bank and thrift regulators began in 1993 to collect data on the aggregate number and amount of small commercial loans outstanding (loans of less than $\$ 1,000,000$ ) at financial institutions, but these data cannot be used to estimate the shares of bank and nonbank lending. They reflect loans made by depository institutions but not loans made by nondepository sources such as brokerage, finance, insurance, and leasing companies.

Surveys of small businesses conducted by trade organizations such as the National Federation of Independent Businesses generally collect information on the incidence of use. Information on dollar amounts by source and loan type are rarely available. See also a 1996 survey conducted for the American Banker by Payment Systems, Inc. ("Credit Lines, Leasing in Demand as Small Businesses' Needs Evolve," American Banker, September 9, 1996, pp. 9-11).

5. The 1993 NSSBF focused on the availability of credit to small and minority-owned businesses, and the 1987 survey focused on the definition of banking markets. Both surveys, however, collected a complete roster of the credit lines, loans, and leases obtained by each firm surveyed, including information on the amount of credit obtained and the identity of the lender. Because of broad changes in the coverage of the two surveys, valid comparisons between 1987 and 1993 data can be made only after statistical adjustments to sampling weights have been made to make them more comparable. See the appendix for a description of these weighting adjustments. For more information about the 1993 NSSBF, see Rebel A. Cole and John D. Wolken, "Financial Services Used by Small Businesses: Evidence from the 1993 National Survey of Small Business Finances," Federal Reserve Bulletin, vol. 81 (July 1995), pp. 629-67. For more information about the 1987 NSSBF, see Gregory E. Elliehausen and John D. Wolken, "Banking Markets and the Use of Financial Services By Small and Medium-Sized Businesses,' Federal Reserve Bulletin, vol. 76 (October 1990), pp. 801-17. erage of the two surveys preclude comparisons of actual dollar amounts. Hence, this analysis cannot address whether total lending to small businesses rose or fell over the period.

This article provides background information about macroeconomic changes that could be expected to have influenced credit conditions over 1987-93, reviews the types of credit supplied to small businesses by banks and nonbanks, and tests whether banks have lost market share to nonbanks. We use two different measures of market share-the percentage of the aggregate dollar amount of credit used by small businesses and the percentage of small businesses using credit.

Overall, our results indicate that small businesses obtained a higher percentage of their credit from nonbanks in 1993 than in 1987 but that this difference was small-about 2.0 percentage points. Banks still provided more than 60 percent of the dollar value of credit, excluding trade credit and credit card debt, and dominated in the provision of credit lines used. However, the percentage of firms obtaining credit from banks dropped significantly, from 44.0 percent in 1987 to only 36.8 percent in 1993 , whereas the percentage of firms obtaining credit from nonbanks was stable at 32 percent. $^{6}$

Within the general category of nonbanks, the data indicate that thrift institutions have lost about half of their dollar share, which fell from 7.4 percent to 4.0 percent, of the small business credit market over 1987-93. The losses of market share by banks and thrift institutions primarily accrued to finance companies, leasing companies, and brokerage firms.

The surveys provide information about the different types of loans and various demographic characteristics of small businesses. Overall, mortgages have become a much smaller share of small business debt, while borrowings under lines of credit became a larger share between 1987 and 1993. The percentage of small businesses that used credit lines, equipment loans, and capital leases rose significantly, while the percentage that used mortgages declined significantly. During this period, banks lost market share disproportionately at medium-sized small businesses and at minority-owned firms.

While the evidence presented here suggests that nonbanks have somewhat eroded banks' share of small business credit, it does not address bank and nonbank competition in the provision of other financial services used by small businesses, the most prominent being checking and savings accounts.

6. Tests of statistical significance are computed for the change statistics as discussed in the appendix. 
Indeed, 87.8 percent of small businesses used commercial banks for financial services during 1993, more than double the percentage of such firms using nonbanks. ${ }^{7}$ Whether banks have gained or lost ground to nonbanks in the provision of noncredit financial services is an interesting topic for future analysis using data from the NSSBF.

\section{BACKGROUND}

The 1980s and early 1990s were periods of tumultuous change for the U.S. commercial banking industry. First, two major banking laws, the Depository Institutions Deregulation and Monetary Control Act of 1980 and the Garn-St Germain Depository Institutions Act of 1982, removed numerous regulations that limited competition among banks and between banks and nonbanks. For example, interest rate ceilings were phased out, and many restrictions on how much banks and thrift institutions could invest in particular asset classes were eased. Additional legislation at the state level eased or removed many limitations on geographic expansion by banks. ${ }^{8}$ Subsequently, a sequence of economic shocks in the 1980s from the collapse of agricultural, oil, and commercial real estate prices contributed to losses that caused banks to fail in numbers not seen since the Great Depression, even though the economy was in an expansion that lasted from 1982 to 1990 . More than 100 banks failed in each year from 1985 to 1992, and more than 200 failed each year in 1987, 1988, and 1989. Presumably, these failures tended to eliminate lessefficient banks, whose assets were transferred to more-efficient competitors, thereby leaving a banking industry better equipped to compete with nonbanks. ${ }^{9}$

7. See Cole and Wolken, "Financial Services Used by Small Businesses."

8. For a description of the changes in state laws, see Dean Amel, "State Laws Affecting the Geographic Expansion of Commercial Banks," Board of Governors of the Federal Reserve System, September 1993; and Donald T. Savage, "Interstate Banking: A Status Report," Federal Reserve Bulletin, vol. 79 (December 1993), pp. 1075-89.

9. A number of studies have found that failing banks are much less efficient than other banks. See Allen N. Berger and David B. Humphrey, "Measurement and Efficiency Issues in Commercial Banking," in Z. Griliches, ed., Output Measurement in the Service Sectors, National Bureau of Economic Research, Studies in Income and Wealth, vol. 56 (University of Chicago Press, 1992), pp. 221-49; Richard Barr and Thomas Siems, Predicting Bank Failure Using DEA to Quantify Management Quality, Federal Reserve Bank of Dallas, Financial Industry Studies Working Paper 1-94, January 1994; Robert DeYoung and Gary Whalen, "Is a Consolidated Banking Industry a More Efficient Banking Industry?" Office of the Comptroller of the Currency, Quarterly Journal, vol. 13 (September 1994), pp. 11-21; and David C. Wheelock and Paul W. Wilson, "Explaining Bank Failures: Deposit Insurance, Regulation, and Efficiency," Review of Economics and Statistics, vol. 77 (November 1995), pp. 689-700.
Following deregulation, the banking industry consolidated sharply via nearly 3,000 mergers during the 1987-93 period. These mergers reduced the ranks of small banks, which tend to specialize in small business lending, as larger banks acquired their smaller competitors. About two-thirds of the acquired banks held less than $\$ 100$ million in assets, while roughly half of the acquirers held more than $\$ 1$ billion in assets. The percentage of industry assets at the largest banks, those with assets of more than $\$ 100$ billion, grew from 12.7 percent at the end of 1986 to 24.1 percent at the end of 1993. Together, bank failures and mergers caused the number of chartered U.S. commercial banks to decline almost one-fourth during the 1987-93 period, from 14,210 to 10,960 . During the same period, however, banking industry assets grew from $\$ 2.94$ billion to $\$ 3.71$ billion.

The 1987-93 period also saw record numbers of failures by nonbank competitors, primarily savings and loan associations and savings banks; because of failures and mergers, these institutions declined by almost half during the period, from 3,677 to 2,262. Unlike banking assets, which rose over this period of consolidation, the assets of savings and loans and savings banks fell, from $\$ 1.39$ trillion to $\$ 1.0$ trillion. Contributing to this divergent experience was the acquisition of the savings institutions' assets by commercial banks.

Largely in response to the record numbers of depository failures and the urging of bank and thrift regulators, the Congress passed two more major banking laws, the Financial Institutions Reform, Recovery, and Enforcement Act of 1989 (FIRREA) and the Federal Deposit Insurance Corporation Improvement Act of 1991 (FDICIA). Together, FIRREA and FDICIA ushered in regulations regarding risk-based capital and prompt corrective action that effectively increased capital requirements for large portions of the banking and thrift industries.

At the same time, the overall weakness of economic activity left many businesses unwilling to take on new debt and, in many cases, unable to service their existing debt. Their plight contributed to record loan losses in the banking industry. Especially hard hit was the market for commercial mortgages, where prices, as measured by the Russell NCREIF Property Index, dropped almost one-third during the 1990-92 period.

The brief recession of 1990-91 included a slowing of credit flows that numerous economic observers characterized as a "credit crunch." Whether the more stringent banking regulations and the supply of bank credit played a role in bringing about these conditions 
1. Bank and nonbank shares of total nonfarm nonfinancial business loans, 1980-96:Q2

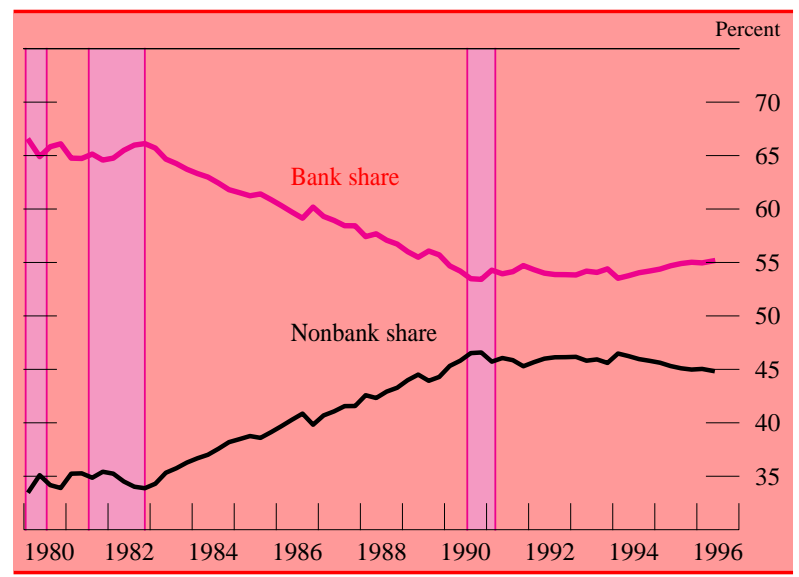

NoTE. Total nonfarm nonfinancial business loans are calculated as the sum of "bank loans" and "other loans and advances" at nonfarm nonfinancial corporations and nonfarm noncorporate businesses, as defined by the Federal Reserve Board's flow of funds accounts. Data are quarterly. Shaded areas denote periods of business recession as defined by the National Bureau of Economic Research.

has been the subject of much debate and is beyond the scope of this article. ${ }^{10}$ However, harsher economic conditions undoubtedly had adverse effects on the use of credit for small businesses, especially the use of mortgage credit. Consequently, any comparisons of credit use in 1987, a year far along into a seven-year expansion, with credit use in 1993, a year early in the current expansion, will undoubtedly be affected by differences in macroeconomic conditions.

The combination of loan losses, the weak economy, and more stringent regulation led many depositories initially to tighten the terms and standards for underwriting commercial loans and strengthen their capital positions. A Board survey of senior loan officers indicated that standards for approving commercial loans tightened, on net, throughout 1990-92 and only began to ease during 1993. And bank Call Report data show that the average leverage capital ratio for the industry rose from 6.2 percent in 1990 to 7.6 percent in 1993.

10. Joe Peek and Eric Rosengren link regulatory enforcement actions and the shrinkage of bank loans to sectors likely to be bank dependent ("Bank Regulation and the Credit Crunch," Journal of Banking and Finance, vol. 19, 1995, pp. 679-92), and tie changes in bank capital to changes in deposits ("The Capital Crunch: Neither a Borrower nor a Lender Be," Journal of Money, Credit, and Banking, vol. 27, August 1995, pp. 625-38). In contrast, Allen N. Berger and Gregory S. Udell conclude that the quantitative effects of the new capital regulations were not substantial ("Did Risk-Based Capital Allocate Bank Credit and Cause a Credit Crunch in the U.S.?" Journal of Money, Credit, and Banking, vol. 26, August 1994, pp. 585-628). However, they do not rule out regulatory pressure as a reason for some of the banking industry's credit reallocation during the early 1990 s.
In this article, market shares rather than aggregate dollar amounts are compared. If all types of lenders and borrowers react to the business cycle in a similar fashion, then these comparisons should be valid. If, however, during a recession, banks reduce lending more than nonbank lenders, some of the observed changes in market shares would be a result of these differing responses. But banks' share declined throughout the 1987-90 period (chart 1) and increased during the latter stages of the 1990-91 recession. Hence, the overall decline in banks' dollar share of small business lending should not be attributed to differing responses to the recession.

\section{TYPES OF CREDIT USED BY SMALL BUSINESSES}

Both of the NSSBFs collected information on six types of credit to small businesses-credit lines used, mortgage loans, equipment loans, motor vehicle loans, capital leases, and "other" loans. ${ }^{11}$ Credit lines used represent loans taken down under an agreement by a lender to provide up to a specified amount of credit for part or all of a specified period. Because the borrower has the option of taking down part or all of the credit for part or all of the specified period, credit lines provide the most flexibility in funding. Credit lines are typically used to finance working capital needs and are often collateralized by assets unrelated to the use of the credit line. In contrast, mortgage loans, equipment loans, motor vehicle loans, and capital leases are typically used to finance specific assets and are typically collateralized by the assets being financed. "Other" loans refer to loans not elsewhere classified, primarily unsecured term loans and loans collateralized by assets other than real estate, equipment, and motor vehicles and not taken down under credit lines. ${ }^{12}$

From 1987 to 1993 , the distribution of the total dollar value of credit used by small businesses across loan types changed significantly (table 1). In both years, about three-fifths of the aggregate dollar amount of small business credit was in the form of credit lines used and mortgages; but in 1993, the

11. Both surveys collected information about trade credit, and the 1993 survey also collected information about credit card debt used for business purposes; these two types of credit are not analyzed in this article.

12. Other loans refer to loans that a survey respondent reported after being queried about any credit lines, mortgages, equipment loans, motor vehicle loans, and capital leases. Some of the loans classified as "other" likely should be in another category, but the surveys did not collect sufficient information to permit accurate reclassifications. 
1. Distribution of the dollar amount of small business credit outstanding, by credit type, 1987 and 1993

Percent except as noted

\begin{tabular}{|c|c|c|c|}
\hline Credit type & 1987 & 1993 & $\begin{array}{c}\text { Change } \\
\text { (percentage } \\
\text { points) }\end{array}$ \\
\hline Credit lines used ${ }^{1}$ & 34.0 & 44.1 & $10.1 *$ \\
\hline Mortgage loans ${ }^{2}$. & 31.2 & 13.9 & $-17.3 *$ \\
\hline Equipment loans ... & 10.5 & 11.3 & .8 \\
\hline Motor vehicle loans & 6.1 & 6.0 & -.1 \\
\hline Capital leases ..... & 4.0 & 6.2 & $2.2 *$ \\
\hline Other loans ${ }^{3}$ & 14.3 & 18.6 & $4.4 *$ \\
\hline Total & 100 & 100 & $\ldots$ \\
\hline
\end{tabular}

1. Amounts drawn down under credit lines.

2. Includes both commercial mortgages and residential mortgages if funds were used for business purposes.

3 . For definition, see text note 12 .

* Statistically significant at the 95 percent confidence level (that is, the probability that any change occurred with the same sign is at least 95 percent). See the appendix for a discussion of some of the statistical techniques used.

share for mortgages had plummeted from 31.2 percent to only 13.9 percent, while that for credit lines used had risen from 34.0 percent to 44.1 percent. Much of this shift may be attributed to upheavals in the commercial real estate market, in which, as noted previously, property values declined almost one-third during the early 1990s. To the extent that these properties were leveraged, borrowers passed losses on to mortgage lenders, who responded by curtailing new real estate lending. With the exception of motor vehicle loans, other types of credit (equipment loans, capital leases, and other loans) registered small gains in market share from 1987 to 1993 at the expense of mortgages. These results are consistent with the 1996 survey conducted for the American Banker, which showed that small businesses have increased their reliance on credit lines and leases at the expense of traditional loans. ${ }^{13}$

The same overall trends in the types of credit used by small businesses are also evident in the shares of different credit types held by banks and nonbanks, in that credit lines used grew in importance while mortgages declined in importance (table 2). However, the proportions of credit types in the portfolios of banks and nonbanks are quite different. In 1993, for example, credit lines used accounted for more than half of all bank credit extended to small businesses but only slightly more than one-fourth of all nonbank credit to small businesses.

Among nonbanks, thrift institutions shifted their portfolio out of mortgages and into each of the five other types of credit, more than doubling their allocation to equipment and motor vehicle loans (table 3). Finance companies reduced their allocation to mort-

13. See "Credit Lines, Leasing in Demand."
2. Comparison of the distributions of the dollar amount of small business credit outstanding at banks and nonbanks, by credit type, 1987 and 1993

Percent except as noted

\begin{tabular}{|c|c|c|c|c|c|c|}
\hline \multirow[b]{2}{*}{ Credit type } & \multicolumn{3}{|c|}{ Banks } & \multicolumn{3}{|c|}{ Nonbanks ${ }^{1}$} \\
\hline & 1987 & 1993 & $\begin{array}{c}\text { Change } \\
\text { (percent- } \\
\text { age } \\
\text { points) }\end{array}$ & 1987 & 1993 & $\begin{array}{c}\text { Change } \\
\text { (percent- } \\
\text { age } \\
\text { points) }\end{array}$ \\
\hline Credit lines used ${ }^{2}$ & 41.9 & 55.2 & 13.3 & 20.3 & 26.4 & 6.1 \\
\hline Mortgage loans ${ }^{3}$ & 31.0 & 14.4 & -13.4 & 31.4 & 13.2 & -18.2 \\
\hline Equipment loans .... & 10.0 & 11.0 & 1.0 & 11.4 & 11.7 & .3 \\
\hline Motor vehicle loans & 5.1 & $\begin{array}{r}11.0 \\
4.9\end{array}$ & $\begin{array}{l}1.0 \\
-.2\end{array}$ & $\begin{array}{r}1.4 \\
7.9\end{array}$ & 7.7 & -.2 \\
\hline Capital leases ..... & 1.5 & 2.8 & 1.3 & 8.4 & 11.6 & 3.2 \\
\hline Other loans ${ }^{4}$ & 10.6 & 11.7 & 1.1 & 20.6 & 29.5 & 8.9 \\
\hline Total & 100 & 100 & $\ldots$ & 100 & 100 & $\ldots$ \\
\hline
\end{tabular}

1. Nonbanks consist of thrift institutions (savings and loan associations, savings banks, and credit unions), finance companies, insurance companies, mortgage companies, leasing companies, brokerage firms, other business firms, families and individuals, and government sources of credit.

2. Amounts drawn down under credit lines.

3. Includes both commercial mortgages and residential mortgages if funds were used for business purposes.

4. For definition, see text note 12 .

gages only slightly, while shifting portfolio share from equipment, motor vehicle, and other loans into credit lines used. As a result of these changes, in 1993 credit lines used accounted for more than half of all finance company lending to small businesses. Nonbanks other than thrift institutions and finance companies were the only group of lenders whose portfolio share of credit lines used declined from 1987 to 1993 . Other nonbanks shifted out of mortgages primarily into other loans.

\section{BANK AND NONBANK SHARES OF SMALL BUSINESS CREDIT}

From 1987 to 1993, banks lost to nonbanks 2 percentage points of their share of the small business credit market (table 4). This finding is consistent with the hypothesis that nonbanks are eroding banks' market share of credit to firms that are too small to gain direct access to money and capital markets. The magnitude of the decline is small, however (banks still had three-fifths of the market in 1993) and lacks statistical significance. ${ }^{14}$ Moreover, bank lending to businesses has rebounded strongly since 1993. Evidence from bank Call Reports shows that, after declining from $\$ 633$ billion as of June 1991 to $\$ 593$ billion as of June 1993, commercial and industrial loans grew to $\$ 737$ billion as of June 1996 . This growth in overall business lending suggests that

14. The estimated 2 percent decline in the bank share is significantly different from zero at the 74 percent level of confidence. 
3. Distribution of the dollar amount of small business credit at nonbank sources, by type of credit, 1987 and 1993 Percent except as noted

\begin{tabular}{|c|c|c|c|c|c|c|c|c|c|}
\hline \multirow[b]{2}{*}{ Credit type } & \multicolumn{3}{|c|}{ Thrift institution } & \multicolumn{3}{|c|}{ Finance company } & \multicolumn{3}{|c|}{ Other nonbank ${ }^{1}$} \\
\hline & 1987 & 1993 & $\begin{array}{c}\text { Change } \\
\text { (percentage } \\
\text { points) }\end{array}$ & 1987 & 1993 & $\begin{array}{c}\text { Change } \\
\text { (percentage } \\
\text { points) }\end{array}$ & 1987 & 1993 & $\begin{array}{c}\text { Change } \\
\text { (percentage } \\
\text { points) }\end{array}$ \\
\hline Credit lines used ${ }^{2}$ & 16.8 & 22.4 & 5.6 & 32.3 & 51.2 & 18.9 & 14.2 & 8.9 & -5.3 \\
\hline Mortgage loans ${ }^{3}$ & 60.9 & 39.3 & -21.6 & 7.5 & 6.3 & -1.2 & 34.4 & 13.0 & -21.4 \\
\hline Equipment loans ... & 1.6 & 6.1 & 4.5 & 22.5 & 16.7 & -5.8 & 8.5 & 9.1 & .6 \\
\hline Motor vehicle loans & 3.1 & 7.4 & 4.3 & 20.0 & 14.5 & -5.5 & 2.1 & 2.7 & 6 \\
\hline Capital leases ..... & 3.8 & 5.9 & 2.1 & 5.4 & 7.4 & 2.0 & 12.1 & 15.8 & 3.7 \\
\hline Other loans ${ }^{4} \ldots \ldots$ & 13.7 & 18.8 & 5.1 & 12.2 & 3.9 & -8.3 & 28.7 & 50.5 & 21.8 \\
\hline Total & 100 & 100 & $\ldots$ & 100 & 100 & $\ldots$ & 100 & 100 & $\ldots$ \\
\hline
\end{tabular}

1. Other nonbanks consist of brokerage firms, leasing companies, insurance and mortgage companies, other business firms, government sources, and individuals.

2. Amounts drawn down under credit lines.

banks may have regained market share in the small business credit market since the 1993 NSSBF.

Changes in bank and nonbank shares of the total dollar amount of small business credit from 1987 to 1993 varied by type of credit (table 4). Mortgage loans' share of small business credit declined more than half at both banks and nonbanks, with bank mortgages falling from 19.7 percent to 8.8 percent of the small business credit market and nonbank mortgages falling from 11.5 percent to 5.1 percent. The changes for credit lines, however, were quite different at banks and nonbanks. Bank credit lines grew by just more than one-fourth to 33.8 percent, while nonbank credit lines grew by more than one-third to 10.2 percent. These figures suggest that nonbanks increased their share of the market for small business credit lines used over the same period that credit lines were growing in importance to small businesses. In another development, capital leases grew in importance for both banks and nonbanks. Bank capital leases almost doubled from 0.9 percent to 1.7 percent of all small
3. Includes both commercial mortgages and residential mortgages if funds were used for business purposes.

4. For definition, see text note 12 .

business credit, while nonbank capital leases grew from 3.1 percent to 4.5 percent.

To see how these changes in market shares affected specific types of nonbanks, credit shares of each type of nonbank are shown in table 5. As the thrift industry declined over 1987-93, thrift institutions' share of small business credit fell from 7.4 percent to 4.0 percent. When combined with commercial banks' decline of 2.0 percentage points, depository institutions (commercial banks and thrift institutions) lost 5.4 percentage points of market share to nondepository nonbanks. Finance companies reaped the greatest gain in market share, with an increase from 11.4 percent to 14.7 percent. Leasing companies more than doubled their market share from 1.5 percent to 3.5 percent, while brokerage companies increased their share from an almost nonexistent 0.1 percent to 1.4 percent. ${ }^{15}$ Insurance and mortgage

15. Brokerage company credit consists primarily of lines of credit used.

4. Distribution of the dollar amount of all small business credit outstanding, by type of credit at banks and nonbanks, 1987 and 1993

Percent except as noted

\begin{tabular}{|c|c|c|c|c|c|c|c|c|}
\hline \multirow[b]{2}{*}{ Credit type } & \multicolumn{3}{|c|}{ Bank } & \multicolumn{3}{|c|}{ Nonbank } & \multicolumn{2}{|c|}{ Total } \\
\hline & 1987 & 1993 & $\begin{array}{c}\text { Change } \\
\text { (percentage } \\
\text { points) }\end{array}$ & 1987 & 1993 & $\begin{array}{c}\text { Change } \\
\text { (percentage } \\
\text { points) }\end{array}$ & 1987 & 1993 \\
\hline Credit lines used ${ }^{1}$ & 26.5 & 33.8 & $7.3 *$ & 7.5 & 10.2 & 2.7 & 34.0 & 44.1 \\
\hline Mortgage loans ${ }^{2}$. & 19.7 & 8.8 & $-10.8 *$ & 11.5 & 5.1 & $-6.4 *$ & 31.2 & 13.9 \\
\hline Equipment loans ... & 6.3 & 6.8 & .5 & 4.2 & 4.5 & .3 & 10.5 & 11.3 \\
\hline Motor vehicle loans & 3.2 & 3.0 & -.2 & 2.9 & 3.0 & .1 & 6.1 & 6.0 \\
\hline Capital leases ..... & .9 & 1.7 & $.8 *$ & 3.1 & 4.5 & $1.4 *$ & 4.0 & 6.2 \\
\hline Other loans ${ }^{3}$ & 6.7 & 7.2 & .5 & 7.6 & 11.4 & $3.8 *$ & 14.3 & 18.6 \\
\hline All & 63.3 & 61.3 & -2.0 & 36.7 & 38.7 & +2.0 & 100 & 100 \\
\hline
\end{tabular}

1. Amounts drawn down under credit lines.

2. Includes both commercial mortgages and residential mortgages if funds were used for business purposes.

3. For definition, see text note 12 .

* Statistically significant at the 95 percent confidence level.

** Statistically significant at the 90 percent confidence level. See the appendix. 
5. Distribution of the dollar amount of all small business credit outstanding, by type of credit and type of nonbank, 1987 and 1993

Percent

\begin{tabular}{|c|c|c|c|c|c|c|c|c|c|c|c|c|c|c|c|c|}
\hline \multirow[t]{2}{*}{ Credit type } & \multicolumn{2}{|c|}{$\begin{array}{l}\text { Thrift } \\
\text { institution }\end{array}$} & \multicolumn{2}{|c|}{$\begin{array}{l}\text { Finance } \\
\text { company }\end{array}$} & \multicolumn{2}{|c|}{$\begin{array}{l}\text { Brokerage } \\
\text { company }\end{array}$} & \multicolumn{2}{|c|}{$\begin{array}{l}\text { Leasing } \\
\text { company }\end{array}$} & \multicolumn{2}{|c|}{$\begin{array}{l}\text { Insurance } \\
\text { and mortgage } \\
\text { companies }\end{array}$} & \multicolumn{2}{|c|}{$\begin{array}{l}\text { Business and } \\
\text { government }\end{array}$} & \multicolumn{2}{|c|}{ Individuals } & \multicolumn{2}{|c|}{ Total } \\
\hline & 1987 & 1993 & 1987 & 1993 & 1987 & 1993 & 1987 & 1993 & 1987 & 1993 & 1987 & 1993 & 1987 & 1993 & 1987 & 1993 \\
\hline Credit lines used ${ }^{1}$ & 1.2 & .9 & 3.7 & 7.5 & .1 & .7 & .0 & .0 & .0 & .1 & 2.4 & .4 & .0 & 6 & 7.5 & 10.2 \\
\hline Mortgage loans ${ }^{2}$ & 4.5 & 1.6 & .9 & .9 & .0 & .3 & .0 & .0 & .9 & .9 & 1.5 & .5 & 3.7 & .9 & 11.5 & 5.1 \\
\hline Equipment loans .... & .1 & .2 & 2.6 & 2.5 & .0 & .0 & .1 & 6 & .1 & .1 & 1.0 & .9 & .4 & .2 & 4.2 & 4.5 \\
\hline Motor vehicle loans. & .2 & .3 & 2.3 & 2.1 & .0 & .0 & .1 & .3 & .0 & .0 & .3 & .1 & .0 & .1 & 2.9 & 3.0 \\
\hline Capital leases ...... & .3 & .2 & 6 & 1.1 & .0 & .0 & 1.2 & 2.5 & .0 & .0 & .8 & .3 & .2 & .4 & 3.1 & 4.5 \\
\hline Other loans $^{3} \ldots$. & 1.0 & .8 & 1.4 & .6 & .0 & .4 & .0 & .0 & .4 & .8 & 1.7 & 4.1 & 3.0 & 4.7 & 7.6 & 11.4 \\
\hline Total & 7.4 & 4.0 & 11.4 & 14.7 & .1 & 1.4 & 1.5 & 3.5 & 1.4 & 1.9 & 7.6 & 6.3 & 7.3 & 6.8 & 36.7 & 38.7 \\
\hline
\end{tabular}

Note. Components may not sum to totals because of rounding.

1. Amounts drawn down under lines of credit.

3. For definition, see text note 12 .

2. Includes both commercial mortgages and residential mortgages if funds were used for business purposes.

companies saw a modest gain, whereas the shares of credit extended by other business firms and government and by individuals dropped.

A slightly different perspective on the relative importance of bank and nonbank lending is gained by looking at changes in their shares of the total outstanding dollar amount of each credit type (table 6). ${ }^{16}$ Banks suffered losses in the market shares of credit lines used, motor vehicle loans, and other loans, while gaining share in the markets for capital leases and, to a lesser extent, for mortgages.

16. The data in tables 4 and 5 are used to calculate bank and nonbank market shares of the total outstanding dollar amount of each credit type. Each credit type's bank and nonbank share of total credit is divided by the sum of bank and nonbank shares. For example, in 1987 bank credit lines accounted for 26.5 percent of all small business credit, and nonbank credit lines accounted for an additional 7.5 percent, for a total of 34.0 percent. Banks' share of the market for small business credit lines is then calculated as 26.5 percent divided by 34.0 percent, which yields 77.9 percent as the bank share of the small business market for credit lines. Repeating these calculations for each loan type produces the figures in tables 6 and 7. (Figures in the tables may be slightly different because of rounding.)
Changes in market shares of the total dollar amount of each credit type also were evident among different types of nonbanks (table 7). Thrift institutions lost almost half of their shares of credit lines used, capital leases, and other loans, but doubled their share of equipment loans and made sizable gains in their share of motor vehicle loans. Finance companies made strong gains in the market for credit lines, increasing their share 6.3 percentage points from 10.8 percent to 17.1 percent. Finance companies also more than doubled their presence in the small business market for mortgage credit. This increase should be kept in perspective, however, as the mortgage share of all small business credit declined more than half over this period (table 1). Other nonbanks registered large gains in the market for other loans, with individuals and other businesses and government being the primary sources for these loans.

A comparison of the bank and nonbank shares of the aggregate amount of credit used by small businesses as categorized by various characteristics of the firms and their primary owners also shows changes from 1987 to 1993 (table 8). Banks lost market share

6. Distribution of the dollar amount of each type of small business credit outstanding at banks and nonbanks, 1987 and 1993 Percent except as noted

\begin{tabular}{|c|c|c|c|c|c|c|c|c|}
\hline \multirow[b]{2}{*}{ Credit type } & \multicolumn{3}{|c|}{ Banks } & \multicolumn{3}{|c|}{ Nonbanks } & \multicolumn{2}{|c|}{ Total } \\
\hline & 1987 & 1993 & $\begin{array}{l}\text { Change } \\
\text { (percentage } \\
\text { points) }\end{array}$ & 1987 & 1993 & $\begin{array}{l}\text { Change } \\
\text { (percentage } \\
\text { points) }\end{array}$ & 1987 & 1993 \\
\hline Credit lines used ${ }^{1}$. & 78.0 & 76.8 & -1.2 & 22.0 & 23.2 & 1.2 & 100 & 100 \\
\hline Mortgage loans ${ }^{2}$. & 63.1 & 63.4 & .3 & 36.9 & 36.6 & -.3 & 100 & 100 \\
\hline Equipment loans ........ & 60.0 & 60.0 & .0 & 40.0 & 40.0 & .0 & 100 & 100 \\
\hline Motor vehicle loans .... & 52.5 & 50.0 & -2.5 & 47.5 & 50.0 & 2.5 & 100 & 100 \\
\hline Capital leases ..... & 23.0 & 28.0 & 5.0 & 77.0 & 72.0 & -5.0 & 100 & 100 \\
\hline Other loans ${ }^{3}$. & 46.9 & 38.6 & -8.3 & 53.1 & 61.4 & 8.3 & 100 & 100 \\
\hline All & 63.3 & 61.3 & -2.0 & 36.7 & 38.7 & 2.0 & 100 & 100 \\
\hline
\end{tabular}


primarily at medium-sized small businesses (firms with 5-19 employees or between $\$ 100,000$ and $\$ 1$ million in annual sales), which account for approximately one-fourth of all small business credit (memo columns). Although banks' market share of credit used by women-owned firms increased from 50.1 to 54.5 percent, their market share of credit used by minority-owned firms fell 13.2 percentage points, from 66.4 to 53.2 percent.

Banks gained market share in markets where competition among banks (as measured by the Herfindahl concentration index) was low or high, but lost share where competition among banks was classified as moderate (table 8 ). ${ }^{17}$ In high-concentration markets, primarily small rural areas, local banks face little competition from other banks or from nonbanks and, therefore, would be expected to maintain their share. In fact, banks gained market share in rural markets while losing share in urban markets. In mediumconcentration markets, which tend to be smaller urban and larger rural areas, banks faced limited competition from other banks and from nonbanks, but nonetheless clearly lost market share to nonbanks. In low-concentration markets, primarily large urban areas, banks compete vigorously both with other banks and with nonbanks and have gained market share. This suggests that nonbanks are more effective when competing with banks that are some-

17. The Herfindahl index is a measure of market concentration calculated as the sum of the squares of each bank's market share, which is defined in terms of total bank deposits. The index ranges from zero (perfect competition) to one (perfect monopoly). In this article, markets with indexes of less than 0.10 are considered competitive; those with indexes of 0.10 to 0.18 , moderately concentrated; and those with indexes of more than 0.18 , highly concentrated. These categories correspond to those defined in the "Horizontal Merger Guidelines," issued by the U.S. Department of Justice and the Federal Trade Commission, April 2, 1992. what, but not completely, sheltered from competition. However, there are many different but interrelated factors at work here, so that any definitive conclusions require a more rigorous analysis that accounts for these relationships.

\section{INCIDENCE OF SMALL BUSINESS CREDIT}

This section analyzes the "incidence" of small business credit, which is defined as the percentage of firms using credit of a certain type or from a particular source. In contrast to the analysis of credit shares in the previous section, the analysis of incidence is not dependent on the size of the credit and therefore gives a clearer picture of what sources and types of credit were used by the "typical" small business. ${ }^{18}$

In 1993, 54.1 percent of small businesses used some form of credit, down from 60.1 percent in 1987 (table 9). This finding most likely reflects the different macroeconomic conditions of the two periods but may also reflect other factors, such as the effects of FIRREA, FDICIA, and the growing use of credit card debt to finance small businesses. ${ }^{19}$ As with the

18. Direct comparisons of the number of firms using credit services in 1987 and 1993 should not be made because of differences in the coverage of the two surveys. Both surveys obtained lists of businesses from Dun and Bradstreet, Inc., which expanded its coverage of small, retail, and business service firms in the years between the two surveys. Therefore, the 1993 survey is more broadly representative of such firms, and valid comparisons between the 1987 and 1993 surveys can be made only after accounting for these differences in coverage (see the appendix).

19. Because only the 1993 NSSBF collected data on the use of personal and business credit card debt for business purposes, changes in the use of such debt cannot be analyzed. Nevertheless, use of credit card debt for business was widespread in 1993, with 39.2 percent of firms reporting business use of personal credit card debt and 27.6 percent of firms reporting use of business credit card debt. (See Cole and Wolken, "Financial Services Used by Small Businesses.")

7. Distribution of the dollar amount of each type of small business credit outstanding, by type of nonbank, 1987 and 1993 Percent except as noted

\begin{tabular}{|c|c|c|c|c|c|c|c|c|c|c|c|}
\hline \multirow[b]{2}{*}{ Credit type } & \multicolumn{3}{|c|}{ Thrift institutions } & \multicolumn{3}{|c|}{ Finance companies } & \multicolumn{3}{|c|}{ Other nonbanks ${ }^{1}$} & \multicolumn{2}{|c|}{ Mемо: Nonbank total } \\
\hline & 1987 & 1993 & $\begin{array}{c}\text { Change } \\
\text { (percentage } \\
\text { points) }\end{array}$ & 1987 & 1993 & $\begin{array}{c}\text { Change } \\
\text { (percentage } \\
\text { points) }\end{array}$ & 1987 & 1993 & $\begin{array}{c}\text { Change } \\
\text { (percentage } \\
\text { points) }\end{array}$ & 1987 & 1993 \\
\hline Credit lines used ${ }^{2}$ & 3.7 & 2.1 & -1.6 & 10.8 & 17.1 & $6.3 * *$ & 7.5 & 4.0 & -3.5 & 22.0 & 23.2 \\
\hline Mortgage loans $^{3}$. & 14.4 & 11.4 & -3.0 & 2.8 & 6.6 & 3.8 & 19.8 & 18.6 & -1.2 & 36.9 & 36.6 \\
\hline Equipment loans ... & 1.1 & 2.2 & 1.1 & 24.4 & 21.8 & -2.7 & 14.5 & 16.1 & 1.6 & 40 & 40.0 \\
\hline Motor vehicle loans & 3.8 & 5.0 & 1.3 & 37.4 & 35.9 & -1.5 & 6. & 9.1 & 2.8 & 47 & 50.0 \\
\hline Capital leases ..... & 7.1 & 3.8 & -3.2 & 15.6 & 17.4 & 1.8 & 54.3 & 50.7 & -3.6 & 77.0 & 72.0 \\
\hline Other loans ${ }^{4}$. & 7.1 & 4.1 & -3.0 & 9.8 & 3.1 & $-6.7 * *$ & 36.2 & 54.2 & $18.0 *$ & 53.1 & 61.4 \\
\hline All & 7.4 & 4.0 & $-3.4 *$ & 11.4 & 14.7 & 3.3 & 17.9 & 19.9 & 2.0 & 36.7 & 38.7 \\
\hline \multicolumn{12}{|c|}{ 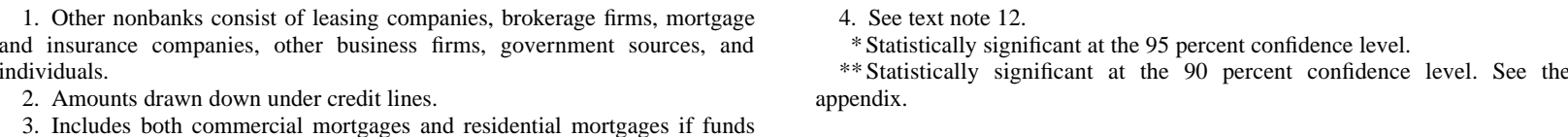 } \\
\hline
\end{tabular}

were used for business purposes. 
8. Total dollar amount of small business credit outstanding, grouped by selected characteristics and distributed by type of issuer, 1987 and 1993

Percent except as noted

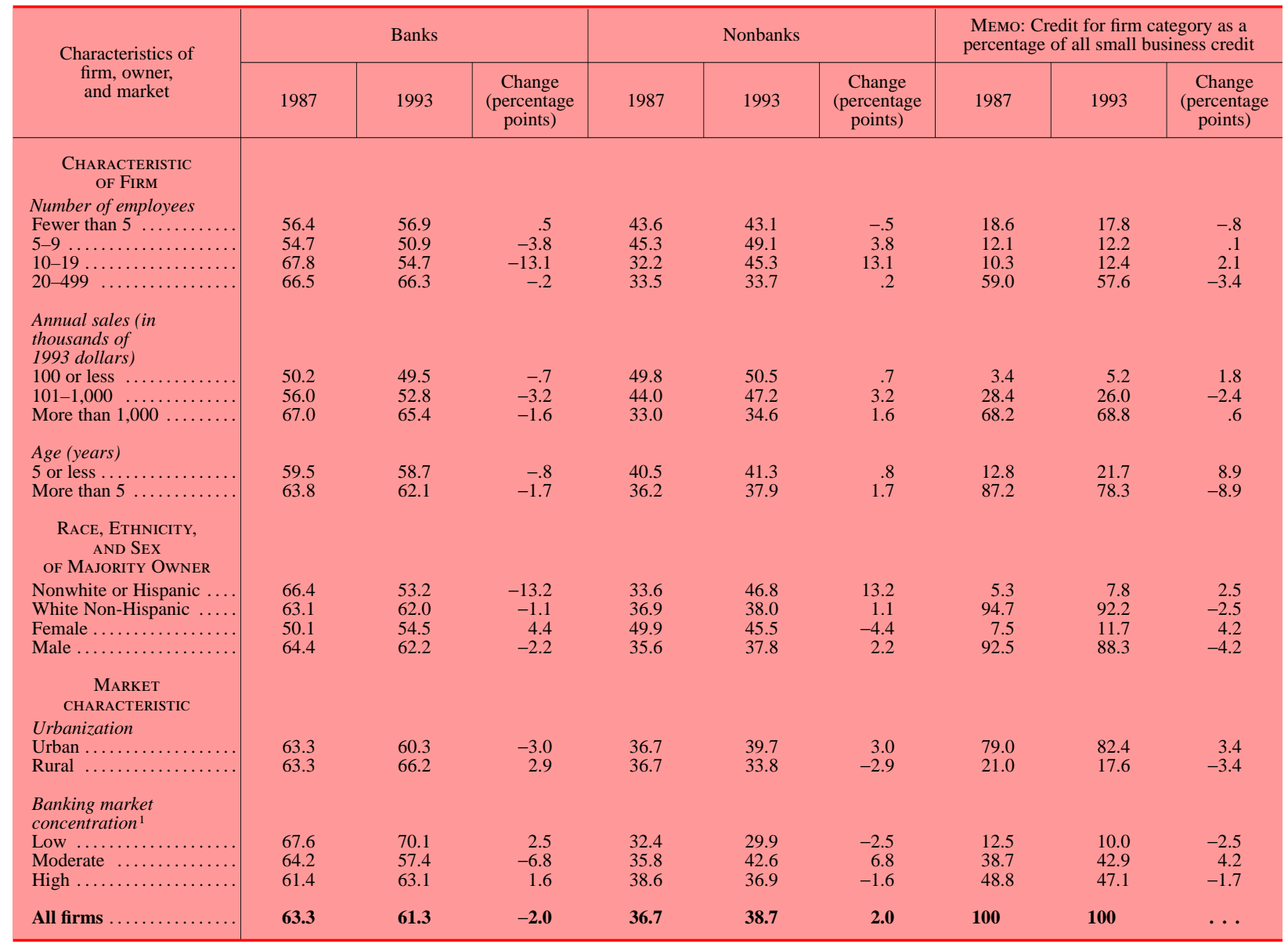

1. As measured by the Herfindahl index. Low $=$ less than 0.10 , moderate $=0.10-0.18$, and high $=$ more than 0.18 .

decline in the dollar share of small business borrowing, the type of credit whose usage (incidence) declined the most is mortgage loans. In both years, the most widely used types of credit were credit lines and motor vehicle loans.

As they did in the case of market share, banks also lost ground to nonbanks in overall credit incidence. From 1987 to 1993, the percentage of small businesses using bank credit services declined from 44.0 percent to 36.8 percent, while the percentage of firms using nonbank credit services was flat at 32.2 percent (table 9). The percentage of small businesses using bank credit services declined for each type of credit except credit lines and capital leases. Banks were the most important supplier of credit lines in both 1987 and 1993 and were used by one out of five small businesses to obtain credit lines-more than four times the incidence for nonbanks. The percentage of small businesses using nonbank credit declined for mortgages and other loans but rose for credit lines, equipment loans, motor vehicle loans, and capital leases. In 1993, nonbanks equaled or exceeded banks in the percentage of small businesses to which they provided capital leases and other loans and trailed only slightly in equipment and motor vehicle loans.

To assess the relative importance of thrift institutions and finance companies among nonbanks, their results are tabulated against those of all other nonbank sources (table 10). The percentage of small businesses using thrift institutions for credit services remained constant from 1987 to 1993, even though thrift institutions lost more than half their share of the dollar value of small business credit over the period. This finding is consistent, however, with the shift by thrift institutions from providing mortgages (-1.2 percentage points), which typically are large in amount, to credit lines ( +0.5 percentage points) and 
9. Percentage of small businesses using selected credit services from all sources and from banks and nonbanks, 1987 and 1993

\begin{tabular}{|c|c|c|c|c|c|c|c|c|c|}
\hline \multirow[b]{2}{*}{ Credit type } & \multicolumn{3}{|c|}{ All sources } & \multicolumn{3}{|c|}{ Bank } & \multicolumn{3}{|c|}{ Nonbank } \\
\hline & 1987 & 1993 & $\begin{array}{c}\text { Change } \\
\text { (percentage } \\
\text { points) }\end{array}$ & 1987 & 1993 & $\begin{array}{c}\text { Change } \\
\text { (percentage } \\
\text { points) }\end{array}$ & 1987 & 1993 & $\begin{array}{c}\text { Change } \\
\text { (percentage } \\
\text { points) }\end{array}$ \\
\hline Any credit $\ldots$ & 60.1 & 54.1 & $-6.1 *$ & 44.0 & 36.8 & $-7.2 *$ & 32.2 & 32.2 & .0 \\
\hline Credit lines ........... & 21.4 & 24.0 & $2.6 *$ & 19.5 & 20.6 & 1.1 & 2.7 & 4.7 & $2.0 *$ \\
\hline Mortgage loans ${ }^{1}$ & 15.5 & 5.8 & $-9.7 *$ & 9.9 & 3.9 & $-6.0 *$ & 6.2 & 2.2 & $-4.0 *$ \\
\hline Equipment loans ... & 12.8 & 13.9 & 1.1 & 7.9 & 7.5 & -.4 & 5.7 & 7.4 & $1.7 *$ \\
\hline Motor vehicle loans & 24.4 & 24.1 & $\begin{array}{l}1.1 \\
-.3\end{array}$ & 14.0 & 13.1 & -.9 & $\begin{array}{r}5.1 \\
11.9\end{array}$ & $\begin{array}{r}1.4 \\
12.7\end{array}$ & .8 \\
\hline Capital leases ..... & 7.2 & 9.1 & $1.9 *$ & 1.7 & 1.7 & .0 & 5.8 & 7.9 & $2.1 *$ \\
\hline Other loans $^{2}$ & 14.1 & 11.0 & $-3.1 *$ & 6.7 & 4.2 & $-2.4 *$ & 8.0 & 7.4 & -.6 \\
\hline
\end{tabular}

1. Includes both commercial mortgages and residential mortgages if funds were used for business purposes.

motor vehicle loans (+0.6 percentage points), which are smaller. In fact, small businesses were more likely to use thrift institutions in 1993 for credit lines and motor vehicle loans than for mortgages.

The percentage of small businesses using finance companies for credit services declined slightly, from 12.0 percent to 11.6 percent. Smaller proportions of firms used finance companies for mortgages, motor vehicle loans, and other loans, while larger proportions used them for credit lines, equipment loans, and capital leases.

In 1993, 19.6 percent of small businesses used other nonbanks (nonbanks other than thrift institutions and finance companies) for credit services, a level 1.2 percentage points higher than in 1987; other nonbanks lost ground only in mortgage loans. Among other nonbanks, leasing companies (not shown in table 10) made the most headway in serving small businesses. The percentage of small businesses borrowing from other nonbanks increased from 4.3 percent in 1987 to 7.6 percent in 1993-a gain accounted for almost entirely by capital leases and motor vehicle loans.

\section{SUMMARY}

This article analyzes data from the National Survey of Small Business Finances for 1987 and for 1993 regarding bank and nonbank competition in the market for small business credit. The results indicate that banks have lost market share but only slightlyabout 2 percentage points. Moreover, bank lending has strongly rebounded since 1993, suggesting that this loss may have been reversed subsequent to the period covered by the surveys.

According to the survey results, banks provided more than 60 percent of the dollar volume of credit in both survey years, excluding trade credit and credit card debt, and dominated in the provision of credit lines. However, the percentage of firms obtaining credit from banks dropped significantly, from 44.0 percent in 1987 to only 36.8 percent in 1993 , while the percentage of firms obtaining credit from nonbanks was stable at about 32 percent. Nonbanks made significant gains in the percentage of small businesses that used them to obtain credit lines, equipment loans, and capital leases; however, banks

10. Percentage of small businesses using selected credit services at selected types of nonbanks, 1987 and 1993

\begin{tabular}{|c|c|c|c|c|c|c|c|c|c|}
\hline \multirow[b]{2}{*}{ Credit type } & \multicolumn{3}{|c|}{ Thrift institution } & \multicolumn{3}{|c|}{ Finance company } & \multicolumn{3}{|c|}{ Other nonbank ${ }^{1}$} \\
\hline & 1987 & 1993 & $\begin{array}{c}\text { Change } \\
\text { (percentage } \\
\text { points) }\end{array}$ & 1987 & 1993 & $\begin{array}{c}\text { Change } \\
\text { (percentage } \\
\text { points) }\end{array}$ & 1987 & 1993 & $\begin{array}{c}\text { Change } \\
\text { (percentage } \\
\text { points) }\end{array}$ \\
\hline Any credit $\ldots$ & 6.1 & 6.1 & .0 & 12.0 & 11.6 & -.4 & 18.4 & 19.6 & 1.2 \\
\hline Credit lines ..... & 1.6 & 2.1 & .5 & .7 & 1.1 & 4 & .5 & 1.6 & 1.1 \\
\hline Mortgage loans ${ }^{2}$ & 2.2 & 1.0 & -1.2 & .5 & .2 & -.3 & 3.7 & 1.0 & -2.7 \\
\hline Equipment loans & .5 & .6 & .1 & 1.6 & 2.0 & 4 & 3.6 & 5.0 & 1.4 \\
\hline Motor vehicle loans & 1.8 & 2.4 & 6 & 8.6 & 7.8 & -.8 & 1.7 & 2.8 & 1.1 \\
\hline Capital leases ...... & .1 & .2 & .1 & 1.2 & 1.9 & .7 & 4.8 & 6.3 & 1.5 \\
\hline Other loans ${ }^{3} \ldots \ldots$ & 1.1 & .5 & -.6 & .4 & .2 & -.2 & 6.6 & 6.7 & .1 \\
\hline
\end{tabular}

Note. Firms may have multiple credit accounts at multiple sources.

1. Other nonbanks consist of leasing companies, brokerage firms, mortgage and insurance companies, other business firms, government sources, and individuals.
2. Includes both commercial mortgages and residential mortgages if funds were used for business purposes.

3. For definition, see text note 12 . 
made significant gains in the percentage of firms using them to obtain mortgages.

Among nonbanks, the data indicate that thrift institutions lost almost half their share of the small business credit market over the 1987-93 period, falling from 7.4 percent to 4.0 percent of the dollar amount of credit. The losses of market share by banks and thrift institutions primarily accrued to finance companies, leasing companies, and brokerage firms.

The results presented here must be viewed with caution. Many of the factors we analyze are interrelated, and definitive conclusions cannot be drawn until more powerful statistical methods can be brought to bear upon this issue. Moreover, we do not examine bank and nonbank competition in the provision of transaction account and financial management services-markets traditionally dominated by banks. These are important and promising areas for future research.

\section{APPENDIX: BACKGROUND, WEIGHTING ADJUSTMENTS, AND VARIANCE ESTIMATES}

The 1987 and 1993 NSSBFs were conducted for different purposes. The 1993 survey focused on the availability of credit to small and minority-owned businesses, whereas the 1987 survey focused on the definition of banking markets. Consequently, respondents to each survey answered a different set of questions, but all respondents provided a complete roster of their firms' finances, including information about the firms' credit lines, loans, and leases. ${ }^{20}$ Interviewers conducted each survey using a system known as computer-assisted telephone interviewing to enter the responses directly into a computerized survey database. Research Triangle Institute conducted the 1987 survey, with the interviews from September 1988 through September 1989. Price Waterhouse conducted the 1993 survey, with interviews from March 1994 through February 1995. The list from which the sample was drawn (the sampling frame) for both surveys was the current (December 1987 and November 1993) Dun and Bradstreet Market Identifier (DMI) file. This continually updated file combines records derived from the traditional Dun and Bradstreet credit-rating program with records derived from business telephone listings. Because the

20. The analysis excluded firms classified as real estate operators, lessors, subdividers, and developers, resulting in the exclusion of 66 firms from the 1987 survey and 101 firms from the 1993 survey. These firms were identified by their respective four-digit Standard Industrial Classifications, 6512 (Real Estate Operators and Lessors) and 6552 (Real Estate Subdividers and Developers).
DMI frame includes firms that are outside the scope of the surveys, interviewers first screened firms for eligibility, then in the full or "primary" interview surveyed eligible firms as well as the firms for which eligibility could not be determined.

The sample selection for both surveys incorporated stratified random sampling with stratification by urbanization of location (that is, urban or rural), number of employees, and census region. Large firms were oversampled in both surveys. However, the two sample designs differed from each other in significant ways. ${ }^{21}$

The 1987 NSSBF used twenty-four strata constructed as follows: two urbanization categories (urban or rural location), three size categories of firms according to the number of employees (1-49, 50-99, and 100 or more), and four Census regions. In 1987 the screening interview yielded an eligibility rate of 66 percent, and the primary interview yielded a 65.5 percent response rate. A set of analysis weights enabled researchers to account for sample design, eligibility, and differential response.

The 1993 NSSBF sample design employed ninetyseven strata constructed from four partitions of the sample frame-one main partition and three minority partitions of likely Asian-, Black-, and Hispanicowned firms respectively. The main partition was divided into ninety sampling strata defined by the two urbanization categories, five size categories of firms according to the number of employees $(1-19,20-49$, 50-99, 100-499, and unknown), and nine Census regions. Each of the three minority partitions was divided by urbanization for a total of six minority strata. A ninety-seventh stratum was defined to account for firms that were listed on the DMI file with more than 500 employees and that had fewer than 500 when surveyed. The best estimate of the eligibility rate is 68.2 percent, and the overall response rate was 59.5 percent. ${ }^{22}$ The computation of the analysis weights for the 1993 survey is more complicated than that for the 1987 survey. For 1993, DMI data were used to compute an adjustment for eligibility and nonresponse.

21. For a detailed description of the 1987 survey, see Brenda G. Cox, Gregory E. Elliehausen, and John D. Wolken, The National Survey of Small Business Finances: Final Methodology Report, RTI Report RTI/4131-OOF (Research Triangle Park, N.C.: Research Triangle Institute, 1989); and for the 1993 survey description, see Price Waterhouse, "The National Survey of Small Business Finances Methodology Report," July 1996.

22. For the 1993 survey, eligibility for a large proportion of the sample could not be determined. Thus, the eligibility rate was estimated assuming different scenarios for the nonrespondents. The best estimate proportionately assigned ineligibility status to the nonrespondents. 
Besides "unit nonresponse"-eligible firms that do not provide interviews-analysts must also account for "item nonresponse" that results when a respondent fails to provide answers to particular questions. Both unit and item nonresponse are important sources of uncertainty. To provide users of the NSSBF data with a complete working dataset, various models were used to impute the missing values from the available data. ${ }^{23}$

\section{Weighting Adjustments}

Analysis weights were adjusted to facilitate proper comparisons of 1987 and 1993 data. Although both surveys used the DMI file as a sampling frame, the types of businesses represented in the file changed significantly between surveys. These changes increased the DMI files' coverage of the smallest firms by adding records for firms identified from third-party lists, such as telephone directories. To adjust for the superior coverage of the 1993 DMI file, the 1987 analysis weights were recalculated so that the distribution of firms by employment size in the 1987 data is the same as that in the 1993 data. $^{24}$

The analysis in this article excluded a small number of firms from each survey because of reporting errors. Each firm with a credit line used, loan, or capital lease accounting for more than 1 percent of the aggregate dollar amount of any credit category was identified. Credit amounts for these firms were then inspected for potential reporting errors that would account for any discrepancies. This inspection identified thirteen firms from the 1987 survey and eighteen firms from the 1993 survey whose data were in error. These firms' records were dropped from the database, and the weights of the remaining firms were recalculated so that the original frequency distribution in each sampling strata was preserved. After these adjustments, the 1987 sample consisted of 3,145 respondents representing 3.2 million firms, and the 1993 sample consisted of 5,237 respondents, representing 4.9 million firms.

23. The imputation was similar to that used for the Board's Survey of Consumer Finances. For details, see Arthur B. Kennickell, "Imputation of the 1989 Survey of Consumer Finances: Stochastic Relaxation and Multiple Imputation," Proceedings of the Section on Survey Research Methods (American Statistical Association, 1991).

24. Ideally, the weights should be adjusted using the precise difference in the coverage of the 1987 and 1993 DMI frames. This information was not available, however, so the 1993 sample estimate was used as a proxy.

\section{Variance Estimates}

To obtain estimates of the change in bank shares and incidence shown in tables $1,4,6,7,8,9$, and 10 , estimates of the sampling variance were calculated for use in tests of statistical significance. Although the sampling variance accounts for the major source of error in a survey, other errors may arise at any stage: for example, a respondent may misinterpret a question; an interviewer may miscode a response; an editor may misinterpret a response. Also, the imputation process itself may be a source of error because of the uncertainty associated with any estimation process. However, the dominant source of error, and the easiest to quantify, is the sampling error. ${ }^{25}$ For the analysis reported here, sampling variances were computed with the replicate method of bootstrap sampling. ${ }^{26}$

Sampling variance can be estimated using "replication methods" that sample from the actual respondents in a way that includes the important dimensions of the original sample design. ${ }^{27}$ The bootstrap method is one such technique that is feasible with the NSSBF. Using the bootstrap method involves sampling with replacement - that is, after each selection, cases are replaced in the sampling pool so that they may be selected in a subsequent draw. This operation was performed 400 times, and a set of analysis weights was computed for each of these 400 replicates. In this model, the sampling error of an estimate computed from the full sample (for example, the proportion of firms using credit) is estimated as the standard deviation computed using the 400 bootstrap estimates.

For the 1987 survey, the replicates were selected to preserve the original sampling strata. The analysis weights for the replicates were computed by adjusting the original analysis weights so that the frequencies estimated within sampling strata remained constant. For the 1993 survey, some of the sampling strata had too few respondents and thus were collapsed within employee size classes into "bootstrap

25. For instance, researchers have shown that sampling error is large relative to imputation error in the 1992 Survey of Consumer Finances. (See Arthur B. Kennickell, Douglas A. McManus, and R. Louise Woodburn, "Weighting Design for the 1992 Survey of Consumer Finances," Board of Governors of the Federal Reserve System, Division of Research and Statistics, 1996.)

26. When sampling designs and desired estimators are complex, replicative variance estimators such as the jackknife and the bootstrap are most appropriate. (See R.R. Sitter, "A Resampling Procedure for Complex Survey Data," Journal of the American Statistical Association, vol. 87 (September 1992), pp. 755-65.)

27. See Jun Shao and Dongsheng Tu, The Jackknife and Bootstrap ((Springer-Verlag, 1995). 
A.1. Distribution of the dollar amount of small business credit outstanding, by credit type, 1987 and 1993

Percent except as noted

\begin{tabular}{|c|c|c|c|}
\hline Credit type & 1987 & 1993 & $\begin{array}{c}\text { Change } \\
\text { (percentage } \\
\text { points) }\end{array}$ \\
\hline Credit lines used $^{1}$ & $\begin{array}{l}34.0 \\
(2.97)\end{array}$ & $\begin{array}{l}44.1 \\
(1.40)\end{array}$ & $\begin{array}{l}10.1 * \\
(3.28)\end{array}$ \\
\hline Mortgage loans ${ }^{2}$. & $\begin{array}{l}31.2 \\
(2.27)\end{array}$ & $\begin{array}{l}13.9 \\
(.77)\end{array}$ & $\begin{array}{r}-17.3 * \\
(2.40)\end{array}$ \\
\hline Equipment loans & $\begin{array}{l}10.5 \\
(1.28)\end{array}$ & $\begin{array}{l}11.3 \\
(.54)\end{array}$ & $\begin{array}{c}.8 \\
(1.39)\end{array}$ \\
\hline Motor vehicle loans & $\begin{array}{l}6.1 \\
(2.13)\end{array}$ & $\begin{array}{l}6.0 \\
(.32)\end{array}$ & $\begin{array}{l}-.1 \\
(2.15)\end{array}$ \\
\hline Capital leases & $\begin{array}{l}4.0 \\
(.52)\end{array}$ & $\begin{array}{l}6.2 \\
(.34)\end{array}$ & $\begin{array}{l}2.2 * \\
(.63)\end{array}$ \\
\hline Other loans ${ }^{3}$ & $\begin{array}{l}14.3 \\
(1.68)\end{array}$ & $\begin{array}{l}18.6 \\
(1.02)\end{array}$ & $\begin{array}{c}4.4 * \\
(1.96)\end{array}$ \\
\hline Total & 100 & 100 & $\ldots$ \\
\hline
\end{tabular}

Note. Standard deviations shown in parentheses.

1. Amounts drawn down under credit lines.

2. Includes both commercial mortgages and residential mortgages if funds were used for business purposes.

3. For definition, see text note 12

* Statistically significant at the 95 percent confidence level.

sampling strata." Analysis weights were then computed so that frequencies within the bootstrap sampling strata remained constant.

With the bootstrap replicates and the associated analysis weights developed, the computation of sampling variance is straightforward albeit intensive. Four hundred bootstrap estimates (one from each bootstrap replicate) were computed. Because the bootstrap estimates represent the sampling distribution of the full-sample estimate, the variance of the bootstrap estimates is the estimate of the sampling variance of the full-sample estimate. For example, the incidence of the use of banks for any credit in 1993 is 36.8 percent (table 9, first line). The bootstrap replicate estimates ranged from 34.9 percent to 38.4 percent, with a median of 36.8 percent and a variance of 0.39 . The same process was repeated for all share and incidence estimates for 1987 and for 1993.

To test the significance of the changes between 1987 and 1993, a $z$ statistic was computed as follows. The full-sample estimate for 1987 was subtracted from that for 1993 to estimate the difference of the share or incidence measure. The standard deviation of this difference is the square root of the sum of the bootstrap variances of the 1987 and 1993 components. The $z$ statistic is then computed as the estimated difference divided by its standard deviation. The $z$ statistics have an approximate standard normal distribution, so that significance levels indicating whether these estimates are significantly different from zero are easily computed. ${ }^{28}$ Table A.1 shows the standard deviations of the data reported in table 1.

28. For an explanation of tests of significance with normal data, see H. Blalock, Jr., Social Statistics (McGraw-Hill, 1972), pp. 93-105. 